\title{
Building bridges between audiovisual translation and English for Specific Purposes $^{1}$
}

\author{
Pilar González-Vera \\ Universidad de Zaragoza (Spain) \\ pilargv@unizar.es
}

\begin{abstract}
Audiovisual translation (AVT) has been exhaustively studied from various perspectives such as Cross-cultural Studies or Reception Studies. More recently, attention has been paid to its value in teaching foreign languages. However, in spite of the numerous descriptive papers on the didactic potential of AVT, relatively few are based on empirical research and even fewer when referring to the teaching of English for Specific Purposes (ESP). Thus, this case study aims to contribute to this field by taking the pulse of the didactic opportunities that AVT, in particular subtitling, offers in ESP and to provide a sample of activities that enhance the development of the skill of listening comprehension by the use of materials which are real and attractive to students.
\end{abstract}

Keywords: ESP, listening skills, AVT, subtitling, didactics.

\section{Resumen}

\section{Tendiendo puentes entre la traducción audiovisual y el inglés para fines especificos}

La traducción audiovisual (TAV) ha sido analizada en profundidad desde distintos prismas como los Estudios Interculturales o los de Recepción. En los últimos tiempos, se ha prestado mayor atención a su valor en la enseñanza de idiomas. Sin embargo, a pesar de los numerosos artículos descriptivos sobre el potencial didáctico de la TAV, muy pocos se basan en investigaciones empíricas y aún son menos los que lo hacen en el contexto de la enseñanza del Inglés para Fines Específicos (IFE). Es por ello que este estudio de caso pretende contribuir a este campo considerando las oportunidades didácticas que la TAV, y en particular la subtitulación, ofrece en el IFE y ofreciendo una muestra de 
actividades que favorezcan el desarrollo de la destreza de comprensión auditiva a través del uso de materiales reales y atractivos para el estudiante.

Palabras clave: IFE, destrezas auditivas, TAV, subtitulación, didáctica.

\section{Introduction}

The role of AVT for didactic purposes is more and more prominent. An example of this is the publication of The didactics of audiovisual translation (Díaz-Cintas, 2008). This volume compiles valuable contributions by leading scholars presenting the place of AVT in teaching English as a Foreign Language. Research on the different modalities of AVT for the development of language skills has been carried out by Talaván and Costal (2017) who work on the potential of intralingual dubbing in EFL, Navarrete (2018) who concentrates on audio description and by Talaván and Ávila-Cabrera (2015) who focus on dubbing and subtitling.

The thorough research by Talaván (2017) can be regarded as a cornerstone of the use of subtitling in EFL. Likewise, the studies by Incalcaterra $(2009,2018)$ and Lertola (2012) prove the importance of subtitling for vocabulary acquisition. Talaván and Rodríguez-Arancón (2014) also carry out interesting research on the use of subtitling for the development of written skills. While their studies focus on the impact of AVT on vocabulary learning and the improvement of writing, this study intends to show the potential of AVT for the development of the skill of listening. The emphasis on the importance of listening is increasing in English as a Foreign Language (EFL) teaching. Studies on the importance of listening in EFL have been given a boost (Nunan, 2002, p. 238) since in the 1980s Krashen's (1982) ideas about the role of comprehensible input in second language acquisition (SLA) gained prominence. However, the methods of approaching listening have barely varied in the classrooms and its implementation has hardly changed. The conventional strategy of listening to the audio tracks of the material included in the course book has remained the only resource in most cases despite some recent lines of research that back the use of authentic materials.

In light of this scenario, this research has a two-fold aim: to contribute to previous studies that evaluate the impact of the use of authentic materials in EFL teaching (Gilmore, 2007; Hwang, 2005); and to provide a sample of activities based on audiovisual translation that can be carried out for the development of listening skills in English for Specific Purposes (ESP) 
classes (cf. Rodríguez-Arancón and Ávila Cabrera's (2019) SubESPSKills project to improve written production skills in ESP). In order to do that, this article will first offer a theoretical view on the teaching of listening skills and the dilemma of whether to use authentic materials or not; second, it will present a case study conducted in the course of Technical English at the School of Engineering and Architecture in the University of Zaragoza.

\section{Listening skills}

Listening can be defined from different perspectives. A broad definition, which will be our point of departure, is "the process of identifying and understanding the speech of the speakers. It involves understanding "the speaker's accent or pronunciation, speaker's grammar and vocabulary, and comprehension of meaning" (Nomass, 2013, p. 111). Listening can also be described in terms of four related activities: sensing, interpreting, evaluating and responding (Steil, Barker and Watson, 1983, pp. 30-36) and it can be classified into five types - discriminative, comprehensive, critical, therapeutic, and appreciative (Wolving \& Coakly, 1982, p. 35). For the present study we will concentrate on comprehensive listening, which helps a listener to understand a message; and on the listening activities of sensing and interpreting - the former referring to receiving messages verbally and nonverbally, and the latter to the process of understanding.

\subsection{Listening as part of communication}

While writing and speaking make up the so-called output skills in EFL, learning, listening and reading form the input skills and "constitute the basic tools of learning as well as the prime media of social intercourse" (Goldstein, 1940, p. 1). Whereas the importance of reading has not been questioned, it was not until the late 1940s that listening was taken seriously and study committees were established despite the fact that Rankin found in 1926 that this skill was the most frequently used mode of human communication (Feyten, 1991, p. 173). Research has demonstrated that adults spend $40-50 \%$ of communication time listening, 25-30\% speaking, $11-16 \%$ reading, and about $9 \%$ writing (Rivers, 1984, p. 331). Similarly, listening comes first as "the key to achieving proficiency in speaking is developing proficiency in listening comprehension” (Dunkel, 1986, p. 100). In other words, the development of communicative competence and oral 
fluency "is achieved by putting the horse (listening comprehension) before the cart (oral production)" (Rhodes, 1987, p. 46).

The importance of listening as an input skill is also highlighted in Krashen's (1992, p. 409) Input Hypothesis that states that language is acquired by understanding messages that constitute the 'comprehensible input'. This language input can be understood by listeners despite them not understanding all the words and structures in it. Giving learners this kind of input helps them acquire language naturally, rather than learn it consciously. The comprehensible input should attempt to offer the acquirers the possibility to move a bit beyond their current level of competence, acquiring a new aspect of language that the acquirers have not mastered yet but are prepared to address ('i+1'). The new structures will be understood with the help of context or extra-linguistic information. In addition, Krashen (1992, p. 411) supports the idea that "'exposure' is primarily of benefit to the intermediate acquirer. For second language acquisition, living in the country helps most when the acquirer already understands at least some of the language".

\subsection{Listening as a skill acquired through education}

In the late 1990s, Field (1998, p. 111) noticed that although the teaching of listening had become more sensitive to the learner's needs, lessons remain predictable in form and content. The continuous disregard of communicative skills in language classrooms was justified by the belief that they were developed "through exposure of the language and practice of grammar” (Hedge, 2000, p. 228). As a consequence of this, neither did books include many sections to training listening and speaking skills, nor did teachers devote much time to such practice in their classes (Gilakjani \& Sabouri, 2016, p. 123). The lack of suggested listening activities in books leads teachers to pay more attention to writing and reading and, as a result of this, students face great struggles to progress in listening. Teachers' awareness of students' critical difficulties with listening is the first step towards developing effective listening strategies to solve their problems with listening (Gilakjani \& Sabouri, 2016, p. 123).

\subsection{Listening as part of communication}

In the late 1990s, Field (1998, p. 111) noticed that although the teaching of listening had become more sensitive to the learner's needs, lessons remain predictable in form and content. The continuous disregard of 
communicative skills in language classrooms was justified by the belief that they were developed "through exposure of the language and practice of grammar" (Hedge, 2000: 228). As a consequence of this, neither did books include many sections to training listening and speaking skills, nor did teachers devote much time to such practice in their classes (Gilakjani \& Sabouri, 2016, p. 123). The lack of suggested listening activities in books leads teachers to pay more attention to writing and reading and, as a result of this, students face great struggles to progress in listening. Teachers' awareness of students' critical difficulties with listening is the first step towards developing effective listening strategies to solve their problems with listening (Gilakjani \& Sabouri, 2016, p. 123).

\section{Effective listening. Authentic and non-authentic materials}

In order to improve listening comprehension abilities, Nunan (2002, p. 241) proposes effective listening courses that will be characterised by:

- Using materials that would be based on a wide range of authentic texts, including both monologues and dialogues.

- Including schema-building tasks before the listening activities.

- Giving learners opportunities to progressively structure their listening by listening to a text several times and by working through increasingly challenging listening tasks.

- Presenting listening tasks in which learners are told what they are listening for and why. These tasks should include opportunities for learners to play an active role in their own learning.

- Including personalised contents which will answer the learners' needs.

On account of this, we can draw the following valuable conclusions: 1) the importance of the use of authentic materials, 2) the need for pre-listening activities that scaffold the learning process, 3 ) the use of an $i+1$ that must be appealing and motivating for students, and 4) students' engagement would be achieved by providing personalised contents in response to the students' needs, for example by providing contents which will be useful at work. 
The preference for authentic materials has been expressed in the last few years by scholars like Gilmore (2007) or Hwang (2005) who maintain that non-authentic materials have the disadvantage of contributing to the adaptation of a teacher-centred model, which is usually associated with a lack of involvement of the students in the activities and their subsequent demotivation, not to mention the handicap of portraying unreal language and contexts. Likewise, Mendelson (2006, p. 76) underlines the fact that nonauthentic materials do not reflect features of the spoken language, as they are ultimately written texts that are then recorded: for example, in nonauthentic materials words are clearly uttered without hesitations or external noises. In these materials it may also be difficult to convey what Mendelson (1994) understands by SIMT (the Setting, the Interpersonal relationships, the Mood and the Topic). The SIMT gathers different types of signals that contribute to the understanding of the message. While setting relies on extralinguistic signals like visuals or background sounds, interpersonal relations and mood rely on paralinguistic signals like voice quality, the distance between speakers or facial expressions. Topic, in turn, is a compilation of linguistic, extralinguistic and paralinguistic signals and can be deduced from the sum of information provided by setting, interpersonal relations and mood. The complexity of piecing together and deciphering all these signals is reduced when using AV authentic materials, not only since they clearly reflect SIMT but also because their visual information helps hearers to confirm or modify their initial guess from the lexical signals.

At this point, we have to say that it is not our intention to show a view of the use of non-authentic materials, but to go for a combination of both types of materials based on the different learning stages, as Mendelson (2006, p. 76) called for. Non-authentic materials would be more convenient for the early stages, as they comprise strategies that teach students "how to" listen. These materials are found in textbooks which still offer helpful guidance and are the central resource in many Spanish EFL classrooms. Nevertheless, their excessive use can be counterproductive. Authentic materials, for their part, would be more advisable for later stages for testing the students' listening. In these cases, students must be prepared to infer in a contextual framework the meaning of new words and cope with conversational features as happens in a real life situation. Authentic materials count on language that is not graded or simplified and they are not preconceived to revolve around a teaching aim, unlike instructional materials. Audiovisual authentic texts include a wide variety of materials such as films, 
TV series, websites, commercials, the news and videogames, which give the student access to the information through more than one channel.

The choice of the materials must be made according to the potential needs of the students, with a view to generating motivation. In the case of ESP the instruction of language is intrinsically linked with their future needs for work. Bearing in mind that a proficient level of English is one of the requirements most in demand, and that the students are self-conscious about their low level in listening (Murphy \& Rodriguez-Manzanares, 2010; Gonzalez-Vera \& Hornero Corisco, 2016), the aim of the ESP lecturer is to foster the students' confidence and development of listening skills in real contexts.

We have observed that the scarcity of listening activities in ESP books is great, and even greater if they are based on authentic materials. This situation contrasts with the fact that at present there are a lot of entertaining TV series and documentaries that revolve around the students' interests and can be used as listening training materials. It is true that designing listening activities around these texts may require a considerable effort but the possibility of getting positive results may make this worthwhile. This was one of the determining factors in conducting a case study based on the use of subtitling to serve as an example to develop and improve listening skills in ESP.

\section{Case study}

\subsection{Context and participants}

This pilot experience within the educational environment was carried out in the course "Technical English" which lasts for 13 weeks and involves 2.5 hours a week of classroom training. Apart from instruction in listening skills, the course entails the development of reading comprehension as well as of the use of English with a special emphasis on technical vocabulary and conventions in written and oral production. At the end of the course, the students enrolled in the course have to take an exam in which all these skills are assessed at B1 level.

A total number of 80 participants from the different specialities of engineering and architecture who were in the final year of their BSc were gathered for this research. They were divided into two groups of 40 people 
each: Group A and Group B. Group A, the experimental group, did the listening activities based on authentic materials, two video clips which were subtitled for this research; while Group B did the listening activities using the same clips but without subtitles.

\subsection{Methodology}

The present study is structured in three stages: 1) a pre-questionnaire that aims to shed light on the students' development of the different skills involved in language learning and, especially, on the way in which they build listening skills, 2) a series of listening activities built on authentic materials (with subtitles for Group A and without subtitles for Group B), and 3) a post-study analysis that involves, on the one hand, the comparison of the students' results in the activities proposed and, on the other hand, a personal questionnaire in which students assess the activities and their level of engagement.

\subsection{Materials}

\subsubsection{Questionnaires}

The materials included two questionnaires, an initial questionnaire distributed via Moodle at the beginning of the project and a postquestionnaire at the end. Apart from these questionnaires, there were three tests based on two video clips edited for our specific purposes which formed the basis of our study.

The pre-questionnaire was designed in an attempt to find out:

a) What level of command of English language (according to the CEFR) the students had,

b) if the students had any certificate in English,

c) the students' perception of their levels in the different skills,

d) how often the students use the Internet and AV materials

e) the frequency with which they watch AV materials both inside and outside the classroom,

f) the AV modality in they prefer to watch AV materials (original version without subtitles, subtitled in English, subtitled in Spanish or dubbed material). 
Once the activities had been done, a final questionnaire concerning the students' personal opinion about the activities proposed was sent out. Its aim was to complement the information received from the objective test results. Thus, students were asked:

a) whether they prefer listening activities that followed traditional formats or those based on subtitling;

b) to describe the usefulness of the activities for improving their linguistic skills in listening, reading and vocabulary;

c) to describe the increase in their self-confidence in their general use of English;

d) whether the proposed activities were entertaining and motivating or not;

e) what type of clips or programmes they would like to work with in the future; and

f) the factors that made the listening activity attractive.

\subsubsection{AV Texts}

Two texts were chosen for this study. The first one was a television documentary from the $\mathrm{BBC}$ about The strongest materials in the world which was broadcast in January 2016. The second one, from 2014, was taken from the television series Top Gear and was about hybrid cars. The choice of these texts was justified by the following factors:

a) the real aspect. Both texts are TV programmes and besides this they were broadcast quite recently which adds a certain proximity in time. This makes the students feel, on the one hand, they can apply and test their language knowledge by understanding a real text and not a stage-managed graded text; and, on the other hand, they could be more strongly attracted by the up-to-date material they are dealing with.

b) the theme. Materials and their properties and hybrid cars are two of the topics covered by the syllabus of the course. In addition, these two topics had been repeatedly chosen by the students for their oral presentations, which indicates their interest in these issues. 
c) the level of the texts (i+1) and the students' familiarity with the specific, technical vocabulary used. As stated before, we agree with the idea of combining non-authentic and authentic materials and the benefits of scaffolding learning. The students previously practised with similar materials taken from a student's book ${ }^{2}$ that introduces specific vocabulary about the properties of materials and about the features of hybrid cars, which are the two topics presented in the clips. Although these clips also include vocabulary and certain comparative structures that students do not know when they watch the clips, the previous acquisition of key vocabulary about those topics allows them to deduce words and expressions they do not know, achieving the $i+1$ stage, and enabling them to grasp the information required in the listening test.

In both cases the clips were self-contained and edited to last no more than six minutes, following the recommendations of scholars like Talaván (2013). Thus, the understanding of the scene selected does not depend on the scenes that precede or follow it and, as the clips are short, the loss of concentration and possible demotivation of students is avoided (Talaván, 2013; Bolanos-Garcia-Escribano, 2017).

For this research, captions were added to the clips. These captions are "written words added onto the clip: e.g. standard subtitles, captions for accessibility, annotations or intertitles" (Sokoli, 2015, p. 129). In the clip on The strongest materials in the world, which lasts 5 minutes, four captions were added. They were four questions in English which fragmented the clip into four parts (Figure 1). The answer to each question is revealed in approximately the following minute where the students have to find out the information. In this way, the students were led throughout the activity in the listening comprehension process. This activity is designed to recall the format of open-ended question activities.

Meanwhile, the four-minute clip from Top Gear was subtitled in English in its entirety. In this case the captions include some gaps preceded by a number reminiscent of the format of "fill in the gaps" activities (Figure 2). 


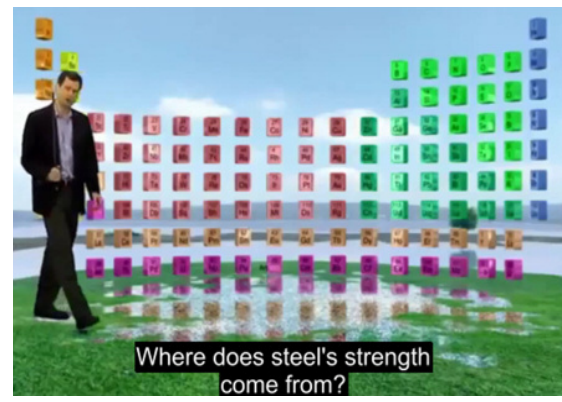

Figure 1. Caption added to The strongest materials in the world.

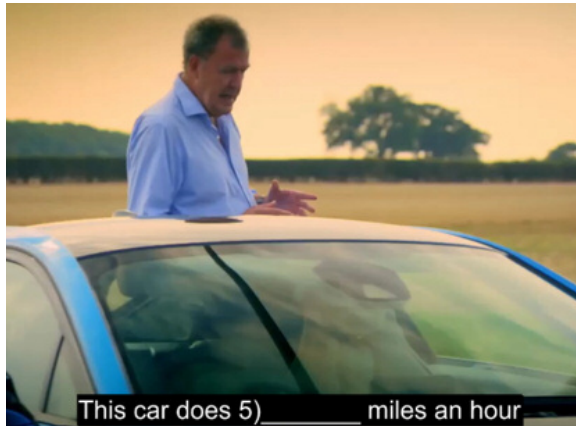

Figure 2. Example of caption created for the clip from Top Gear.

\subsubsection{Tests}

Three of the most common test formats -fill in the gaps, open questions and multiple choice questions- are chosen for testing students' skills. In the BBC documentary about materials open questions and multiple choice formats are selected bearing in mind the type of programme that combines long descriptive voice-over discourses with interviews. In this case, students have to extract and gather different pieces of information in order to answer the questions.

Top Gear is, in turn, a clip where the host's interventions are full of numerical and technical data, and where the content of specific information is much higher in terms of the quantity of words uttered, which in our opinion makes this clip more favourable for a gapfill exercise.

\subsection{Procedure}

Students in Group A are exposed to the clip on The strongest materials in the world. After viewing the first AV text three times, students have to answer the 
questions embedded as captions in the clip. These subtitles help them divide the text into sections that revolve around the questions asked. In addition, students have to take a test, handed out before viewing the clip, consisting of six multiple-choice questions -in paper format, each fragment having one or two of these questions. Students in Group B, by contrast, see the clip without subtitles, although they have access to the visual information provided by the images. Besides, they are also provided with a brief glossary. They listen to the clip the same number of times as the students from Group $\mathrm{A}$ and then they take the same test presented in paper format which is also handed out before watching the clip.

Regarding the test based on Top Gear, a list of numbers is handed out to Group A students before watching the clip. Each of these numbers matches with the numbers that go before the gaps embedded in the subtitles of the clip. They watch the clip three times. Group B students listen to it the same number of times, but they can only have access to the original clip without subtitles. They are given a written test that follows the traditional format of gapfill listening exercises.

\subsection{Results}

\subsubsection{Pre-questionnaire}

The materials included two questionnaires, an initial questionnaire distributed via Moodle at the beginning of the project and a postquestionnaire at the end. Apart from these questionnaires, there were three tests based on two video clips edited for our specific purposes which formed the basis of our study.

The pre-questionnaire, which covered aspects ranging from the students' command of English language to their familiarity with the use of AV materials, reveals that $71.95 \%$ of the students do not have any certificate in English and the level of the majority of those who have (18.35\%) is B1. According to the students' perception, they describe their proficiency in English as intermediate (57\%) and lower-intermediate $(26.7 \%) ; 10.1 \%$ of those remaining consider it to be upper-intermediate and low percentages are found in the case of advanced (4.2\%) and beginners (2\%). Regarding their language skills (Table 1), as a whole we observe that reading is the skill in which most of the students feel more confident, contrasting with the other input skill, listening, in which they declare themselves to be on lower levels of the scale. In addition, the students state that their 
vocabulary knowledge is average, and they admit their weakness in oral skills.

$\begin{array}{lllcccl}\text { Skill } & \text { Very bad } & \text { Bad } & \text { Fair } & \text { Average } & \text { Good } & \text { Very good } \\ \text { Reading } & 0 \% & 2.1 \% & 6.1 \% & 38.8 \% & 42.67 \% & 8.33 \% \\ \text { Listening } & 4.2 \% & 40 \% & 20.1 \% & 14.3 \% & 29.4 \% & 2 \% \\ \text { Speaking } & 2 \% & 45 \% & 16.2 \% & 24.4 \% & 10.3 \% & 2.1 \% \\ \text { Vocabulary } & 2 \% & 45 \% & 16.2 \% & 24.4 \% & 10.3 \% & 2.1 \% \\ & & & & & \end{array}$

The second part of the pre-questionnaire shows a positive change in traditional praxis in the classroom with the incorporation of digital and authentic materials, as $81.6 \%$ of the students admit having used Internet and AV materials in class. The materials preferred are films (36\%) and the DVDs in the student's book (34.7\%); clips from YouTube and TV shows only represent $16.3 \%$ and $13 \%$, respectively. The questionnaire also reveals that the relatively high self-reported frequency of watching AV texts in English (often (25.5\%) and sometimes (23.7\%) versus hardly ever $(20.2 \%)$ and never $(2.1 \%))$ is a strength we should not forget. We should take advantage of this aspect of student motivation as a valuable ally. Lastly, although the modality preferred is dubbing (52.7\%), the value of subtitles seems to be appreciated more and more, being used in English by $17.4 \%$ of the students and in Spanish by a still higher percentage, $24.7 \%$.

\subsubsection{Tests}

As indicated previously, students had to take two tests with different formats. The first clip, The strongest materials in the world, was accompanied by a test that included a section with open questions and another with multiple choice questions. The scores (Figure 3) of Group A, (AV format), were distributed in the open questions test as follows: 0 (5\%, 2 students), $2(17.5 \%, 7$ students), 4 (10\%, 4 students), 6 (15\%, 6 students), 8 (27.5\%, 11 students), $10(25 \%, 10$ students), which means that 27 students $(67.5 \%)$ achieved 6 or more. Group B obtained very weak results in the same test: $0(20 \%, 8$ students), 2 (25\%, 10 students), 4 (32.5\%, 13 students), 6 (10\%, 4 students), 8 (5\%, 2 students) and 10 (7.5\%, 3 students), which means that only 9 students $(22.5 \%)$ achieved 6 or more. 


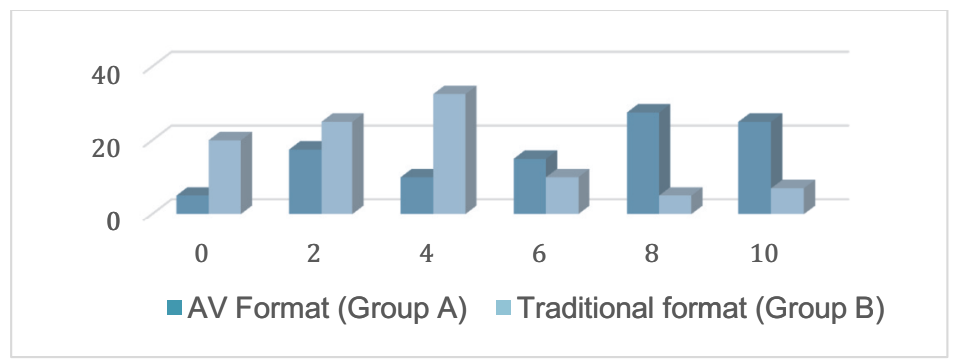

Figure 3. Results in the open question test.

The second test consisted of a multiple choice exercise (Figure 2). The results (Figure 4) of Group A were mainly satisfactory, concentrating in the 6 to 10 range -0 ( $0 \%$, none), 2 (2.5\%, 1 student), 4 (5\%, 2 students), 6 (40\%, 16 students), 8 (22.5\%, 9 students) and 10 (30\%, 12 students), which means that 37 students $(92.5 \%)$ achieved 6 or more. In Group B they were more equally distributed: 0 (5 students), 2 (15\%, 6 students), 4 (12.5\%, 5 students), 6 (22.5\%, 9 students), 8 (20\%, 8 students) and 10 (20\%, 8 students), which means that 25 students $(62.5 \%)$ achieved 6 or more. The differences in results between groups were not notable, except the fact that in Group A none obtained a score of 0 while in Group B 12.5\% did.

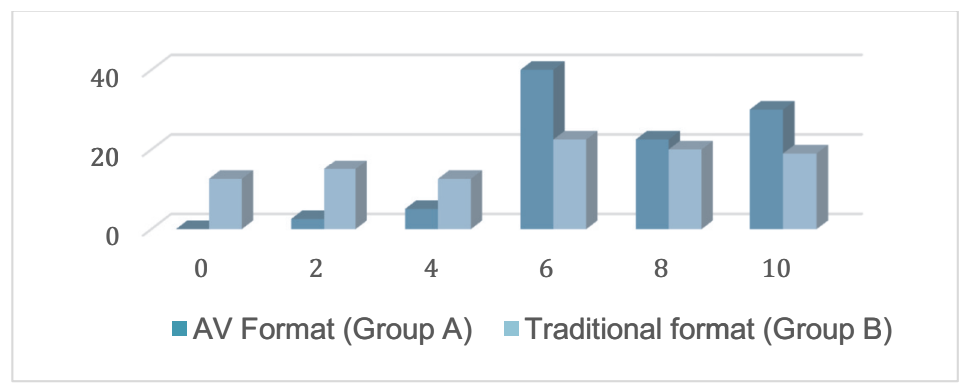

Figure 4. Results in the multiple choice test.

In the third test based on the series Top Gear, the students had to fill in the blanks with one to two words that were used in the audio (Figure 5). Group A were given a gapped text in the form of subtitles, whereas Group B were given a written text with the same number of spaces as in Group A's case and the students only had access to the audio. The words removed from the text were mainly figures and technical vocabulary related to car features. No one in Group A or Group B obtained a score of 0. However, scores below 6 
were mostly found in Group B -2 (20\%, 8 students) and $4(27.5 \%, 11$ students), only $7.5 \%$ of students (3 students) from Group A failed the test, yet even they obtained a score of 4 . Nine students from Group B $(22.5 \%)$ achieved a score of 6 and a similar number of students (10 students, 25\%) a score of 8 . However, the number was considerably reduced in the case of obtaining a score of 10 ( 2 students, $5 \%$ ).

While almost 50\% (19 students) of Group B failed the test, conversely, $47.5 \%$ (19 students) of Group A students got a score of 8, followed by 10 $(32.5 \%, 13$ students $)$ and $6(12.5 \%, 5$ students $)$.

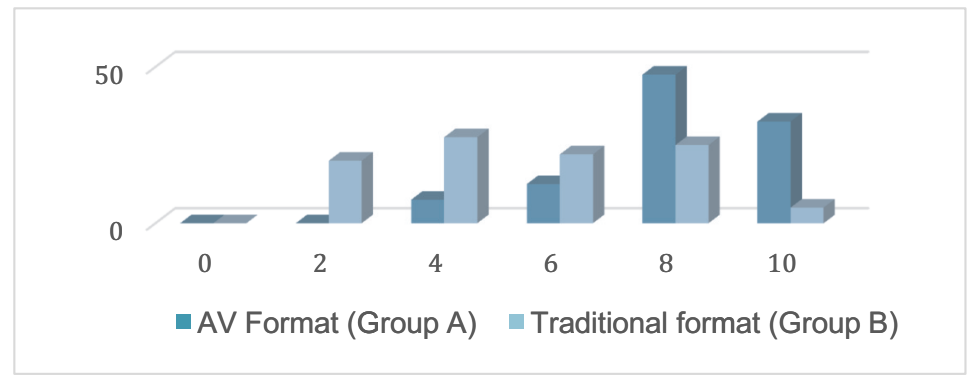

Figure 5. Results in the filling the gaps test.

The following figure (Table 2) summarises the results of Group A and B in the three tests:

\begin{tabular}{|c|c|c|c|c|c|c|}
\hline Score & \multicolumn{2}{|c|}{ Test 1 (Open question) } & \multicolumn{2}{|c|}{ Test 2 (Multiple choice) } & \multicolumn{2}{|c|}{ Test 3 (FIII in the gaps) } \\
\hline 0 & $\begin{array}{l}\text { A } \\
\text { Students (\%) }\end{array}$ & $\begin{array}{l}\text { B } \\
\text { Students (\%) }\end{array}$ & $\begin{array}{l}\text { A } \\
\text { Students (\%) }\end{array}$ & $\begin{array}{l}\text { B } \\
\text { Students (\%) }\end{array}$ & $\begin{array}{l}\text { A } \\
\text { Students (\%) }\end{array}$ & $\begin{array}{l}\text { B } \\
\text { Students (\%) }\end{array}$ \\
\hline 2 & $2(5 \%)$ & $8(20 \%)$ & 0 & $5(12.5 \%)$ & - & - \\
\hline 4 & $7(17.5 \%)$ & $10(25 \%)$ & $1(2.5 \%)$ & $6(15 \%)$ & - & $8(20 \%)$ \\
\hline 6 & $4(10 \%)$ & $13(32.5 \%)$ & $2(5 \%)$ & $5(12.5 \%)$ & $3(7.5 \%)$ & $11(27.5 \%)$ \\
\hline 8 & $6(15 \%)$ & $4(10 \%)$ & $16(40 \%)$ & $9(22.5 \%)$ & $5(12 \%)$ & $9(22.5 \%)$ \\
\hline 10 & $11(27.5 \%)$ & $2(5 \%)$ & $9(22.5 \%)$ & $8(20 \%)$ & $19(47.5 \%)$ & $10(25 \%)$ \\
\hline $6 \leq$ & $27(67.5 \%)$ & $9(22.5 \%)$ & $37(92.5 \%)$ & $25(62.5 \%)$ & $37(92 \%)$ & $21(52.5 \%)$ \\
\hline
\end{tabular}

Table 2. Results in the three tests.

According to the results, the most significant differences between Group A and $B$ in the number of failing scores (scores under 6) arise in Test 1 . It is noteworthy that captions were especially useful for not failing the test with open questions (Test 1). The fragmentation achieved by the captions served to mark the extracts in which the information could be found. In this way, 
captions worked as a "help-guide" helping students in the comprehension process.

In the other two tests ( 2 and 3 ) the differences between the students who pass and who fail the tests in Group A and B were not so marked. However, it can be observed that the number of students who obtained a score of 8 and 10 was dramatically higher in the case of Group A. The "help-guidecaptions" in clip 1 and the captions included in clip 2 that worked as a kind of transcript proved valuable in following the discourse. In addition, in the case of Test 3, the students felt more confident, as they themselves explained after taking the test. The captions included let them identify certain words which were crucial for the understanding of the clip and the general understanding of the clip made them feel more confident.

\subsubsection{Post-questionnaire}

In the final questionnaire, aimed at the students who worked with the subtitled clips, they were asked whether they prefer listening activities that followed traditional formats or those based on subtitling, the latter being chosen by $75 \%$ of the students. The students were also asked about the usefulness of the activities based on AV materials in terms of different linguistic skills. When they had to assess their value for developing listening skills, their response was positive: $48.75 \%$ considered them to be very useful and $37.5 \%$ useful enough, and lower percentages were for not useful enough $(13.75 \%)$ and not useful $(0 \%)$. Similar results were found for vocabulary enhancement where $86.25 \%$ of the students appreciated the benefits of these activities, saying they were useful enough, and $13.75 \%$ said they were very useful. Lastly, reading skills did not obtain such good results although they understood they were useful in some way: $57.5 \%$ answered "not useful enough", $28.75 \%$ "useful enough", $13.75 \%$ very useful and $0 \%$ "not useful".

Equally good results were achieved when they were asked if there was an increase in their self-confidence in their general use of English. Most of them admitted to being satisfied (57.5\%) and some of them to being very satisfied $(7.5 \%)$. A significant percentage of students, $35 \%$, still estimated that this was not enough. This was justified by their demand for more exercises of this type in order to be completely satisfied.

When asked what kind of clips or series they would like to work with on future occasions, the students proposed the following: 
- Car and Motorsport clips like Top Gear

- How it's made?

- Master piece of engineering

- Top 10 architecture

- Programmes about renewable energies

This provides us with information about their interests and with ideas of what type of programmes they may find inspiring and motivating.

Lastly, students considered the following factors decisive in making these listening activities attractive:

- being entertaining: $42,5 \%$

- the topic being related to their interests and having some connection with their degrees: $32,5 \%$

- having visual information that helps them contextualise and understand the discourse: $25 \%$

None of them indicated the speed/pace of the narrator or the accent used as factors that could make these texts easy to follow.

In sum, if we conduct a SWOT analysis of this study of using captions for improving listening skills, we can conclude that among its strengths are: 1) that these activities achieved the development of several skills (reading, vocabulary enhancement, spelling, etc.) at the same time; 2) they were appealing for our students as they could appreciate a practical application that was a source of motivation; and 3) these activities can be implemented inside and outside class via learning platforms like Moodle. We have to add that the students' self-awareness of the need to improve this skill was another motivational factor. With regard to the weaknesses, the time required to select, edit and subtitle the clips is considerable. Nevertheless, the opportunity of peer correction and feedback in the case of the multiple choice and gapfill exercises could be an optimal solution. Likewise, the possibility of designing new activities that cover a wider range of topics would lead to the creation of a bank of clips, an opportunity that would also address the threat of having in the same class a group composed of students that belong to different specialities with different interests. 


\section{Conclusions}

Students have traditionally undergone conventional training in listening skills which is limited to listening activities based on the use of audio tracks. In these non-authentic materials, words are clearly uttered without hesitations or external noises that can interfere with the speaker's discourse and the accent preferred for these recordings is received pronunciation (RP). In spite of being designed for didactic purposes, poor results in listening tests (Woottipong, 2014; Gonzalez-Vera \& Hornero Corisco, 2016) have been the norm for a long time and, unfortunately, this does not seem to be changing, as the students admitted in their initial questionnaire.

There has been an evolution in the study of ways to develop listening skills. These studies have gone from the use of non-authentic to authentic materials. However, the number of case studies on the different strategies to improve listening when using authentic materials has not evolved at the same pace.

Although an increasing interest has been paid in the last decades to studies on the use of different modalities of AVT for the improvement of language skills, thanks to scholars like Lertola (2012), Talaván (2013, 2017), Talaván and Rodríguez-Arancón (2014), Gambier et al. (2015), Talaván and ÁvilaCabrera (2015), Talaván and Costal (2017), Navarrete (2018) and GonzalezVera (2019). The quantity of studies based on AVT modalities for the development of listening in ESP is still limited. Thus, this case study was conceived with the intention of serving as an example of the use of subtitling to improve the teaching and learning of listening skills in the ESP class.

After confirming in the initial questionnaire the level of our students with regard to English and listening skills, in particular, we conducted research based on the use of authentic AV texts and subtitling for fostering the development of listening skills in the case of ESP. This study revealed that results were better in all those instances in which the implementation of the activities relied on subtitling. The results from the implementation stage were backed up by the information obtained in the post-questionnaire and final exam, which was the same across both groups.

Finally, we can conclude by saying that this study is one of the first steps towards confirming the validity of the results of previous research and an attempt to expand the potential of AVT in the teaching of ESP. For the 
future, we would like to consider the possibility of a comparative analysis between a group with a conventional syllabus based on traditional methodologies and another following an AVT based-syllabus, which could explore the feasibility and full potential of AVT in ESP classes.

Article history:

Received 17 September 2019

Received in revised form 07 April 2020

Accepted 30 May 2021

\section{References}

Bolaños García-Escribano, A. (2017). The effects of fansubs on EFL education for Translation and Interpreting students: An empirical approach. Journal of Specialised Translation, 28, 123-164.

Díaz-Cintas, J. (Ed.) (2008). The didactics of audiovisual translation. John Benjamins.

Dunkel, P. (1986). Developing listening fluency in L2: Theoretical principles and pedagogical considerations. Modern Language Journal, 70, 99-106.

Feyten, C. (1991). The power of listening ability: An overlooked dimension in language acquisition. Modern Language Journal, 75(2), 173-180.

Field, J. (1998). Skills and strategies: Towards a new methodology for listening". ELT Journal, 52(2), 110-118.

Gambier, Y., A. Caimi, \& C. Mariotti (Eds.) (2015). Subtitles and language learning. Peter Lang.

Gilakjani, A. P., \& Sabouri, N. B. (2016). Learners' listening comprehension difficulties in English language learning: a literature review. English Language Teaching, 9(6), 123-133.

Gilmore, A. (2007). Authentic materials and authenticity in foreign language learning. Language Teaching, 40(2), 97-118.

Goldstein, H. (1940). Reading and listening comprehension at various controlled rates. Teachers College, Columbia University, 821.

Gonzalez-Vera, P., \& Hornero Corisco, A. (2016). Audiovisual materials: A way to reinforce listening skills in primary school teacher education. Language Value, 8(1), 1-25. Retrieved 04 April 2020 from http://www.languagevalue.uji.es/index. php/languagevalue/article/download/93/91

Gonzalez-Vera, P. (2019). New technologies in the ESP class for mechanical engineers. Argentinian Journal of Applied Linguistics, 7(2), 52-71.
Hwang, C. (2005). Effective EFL education through popular authentic materials. Asian EFL Journal, 7(1), 90-101.

Hedge, T. (2000). Teaching and learning in the language classroom. Oxford University Press.

Ibbotson, M. (2009). Cambridge English for engineering. Cambridge University Press.

Incalcaterra McLoughlin, L. (2009). Intersemiotic translation in foreign language acquisition: The case of subtitles. In T. H. Arnd Witte \& A. Ramos de Oliveira Harden (Eds.), Translation in second language learning and teaching (pp. 227-244). Peter Lang.

Incalcaterra McLoughlin, L. (2018). Audiovisual translation in language teaching and learning. In L. Pérez-González (Ed.), The Routledge handbook of audiovisual translation (pp. 499-513). Routledge.

Krashen, S. (1982). Principles and practice in Second Language Acquisition. Pergamon.

Krashen, S. (1992). The Input Hypothesis: An update. Linguistics and Language Pedagogy: The State of the Art, 409-431.

Lertola, J. (2012). The effect of the subtitling task on vocabulary learning. Translation Research Projects, 4, 61-70.

Mendelsohn, D. (2006). Learning how to listen using learning strategies. In E. Usó-Juan \& A. Martínez-Flor (Eds.) (2006). Current trends in the development and teaching of the four language skills (pp. 75-90). Mouton de Gruyter.

Mendelsohn, D. (1994). Learning to listen: $A$ strategy-based approach for the second language learner. Dominie Press.

Murphy, E., \& Rodriguez-Manzanares, M.A. (2010). The language learning beliefs of selfidentified, successful learners of Spanish as a foreign language. Canadian and International Education, 39(2), 75-89. 
Navarrete, M. (2018). The use of audio description in foreign language education. Translation and translanguaging in multilingual contexts, 4(1), 129-150. https://doi.org/10.1075/ttmc.00007.nav

Nomass, B. B. (2013). The impact of using technology in teaching English as a second language. English Language and Literature Studies, 3(1), 111-116.

Nunan, D. (2002). Listening in language learning. In J. Richards \& W. Renandya (Eds.), Methodology in language teaching: An anthology of current practice (pp. 238-241). Cambridge University Press.

Rivers, W. (1984). What practitioners say about listening: Research implications for the classroom. Foreign Language Annals, 17(4), 331-334.

Rhodes, S. (1987). A study of effective and ineffective listening dyads using the systems theory principle of entropy. Journal of the International Listening Association, 1, 32-53.

Rodríguez-Arancón, P., \& Ávila-Cabrera, J. J. (1719 June 2019). The project SubESPSKills: Subtitling tasks in the English for Specific Purposes class to improve written production skills [Paper presentation]. Media for All 8 Conference, Stockholm. Retrieved 04 April 2020 from https://www.tolk.su.se/english/media-for-all8/programme/abstracts/the-project-subespskills1.422474

Sokoli, S. (2015). Clipflair: Foreign language learning through interactive revoicing and captioning of clips. In Y. Gambier, A. Caimi \& C.
Mariotti C. (Eds.), Subtitles and language learning (pp. 127-148). Peter Lang.

Steil, L., Barker, L., \& Watson, K. (1983). Effective listening: Key to your success. Addison-Wesley.

Talaván Zanón, N. (2013). La subtitulación en el aprendizaje de lenguas extranjeras. Octaedro.

Talaván, N. (2017). Justificación teórico-práctica del uso de los subtítulos en la enseñanzaaprendizaje de lenguas extranjeras. Trans. Revista de Traductología, 16

Talaván, N., \& Rodríguez-Arancón, P. (2014). The use of reverse subtitling as an online collaborative learning tool. The Interpreter and Translator Trainer, 8(1), 84-101. https://doi.org/10.1080/ 1750399X.2014.908559

Talaván, N., \& Ávila-Cabrera, J. J. (2015). First insights into the combination of dubbing and subtitling as L2 didactic tools. In Y. Gambier, A, Caimi \& C. Mariotti (Eds.), Subtitles and language learning (pp. 149-172). Peter Lang.

Talaván, N., \& Costal, T. (2017). iDub - The potential of intralingual dubbing in foreign language learning: How to assess the task. Language Value, 9, 62-88. http://dx.doi. org/10.6035/LanguageV.2017.9.4

Wolving, A., \& Coakly, C. (1982). Listening. Brown. Woottipong, K. (2014). Effect of using video materials in the teaching of listening skills for university students. International Journal of Linguistics, 6(4), 200-212.

Dr Pilar Gonzalez-Vera, lecturer in audiovisual translation and technical English at the University of Zaragoza, is a researcher in the CIRES (Comunicación Internacional y Retos Sociales) group. She has participated in innovative teaching networks for improving listening and writing skills in EFL and has published in several journals on the use of new technologies and audiovisual translation in SLA.

\section{NOTES}

${ }^{1}$ Financial support for this research was provided to the CIRES Group by the Regional Government of Aragon.

${ }^{2}$ Ibbotson, M. (2009). Cambrige English for Engineering. Cambridge: CUP. 